\title{
OPTIMAL DESIGN OF RC FRAMES USING A MODIFIED HYBRID PSOGSA ALGORITHM
}

\author{
SONIA CHUTANI ${ }^{1}$, JAGBIR SINGH ${ }^{2}$
}

\begin{abstract}
The present study has been taken up to emphasize the role of the hybridization process for optimizing a given reinforced concrete (RC) frame. Although various primary techniques have been hybrid in the past with varying degree of success, the effect of hybridization of enhanced versions of standard optimization techniques has found little attention. The focus of the current study is to see if it is possible to maintain and carry the positive effects of enhanced versions of two different techniques while using their hybrid algorithms. For this purpose, enhanced versions of standard particle swarm optimization (PSO) and a standard gravitational search algorithm (GSA), were considered for optimizing an RC frame. The enhanced version of PSO involves its democratization by considering all good and bad experiences of the particles, whereas the enhanced version of the GSA is made self-adaptive by considering a specific range for certain parameters, like the gravitational constant and a set of agents with the best fitness values. The optimization process, being iterative in nature, has been coded in $\mathrm{C}++$. The analysis and design procedure is based on the specifications of Indian codes. Two distinct advantages of enhanced versions of standard PSO and GSA, namely, better capability to escape from local optima and a faster convergence rate, have been tested for the hybrid algorithm. The entire formulation for optimal cost design of a frame includes the cost of beams and columns. The variables of each element of structural frame have been considered as continuous and rounded off appropriately to consider practical limitations. An example has also been considered to emphasize the validity of this optimum design procedure.
\end{abstract}

Keywords: optimum design; reinforced concrete structures; democratic particle swarm optimization; selfadaptive gravitational search algorithm; Indian design standards.

${ }^{1}$ Ph.D. Research Scholar, IKG Punjab Technical University, Kapurthala, Punjab, India, email:soniachutani annie@yahoo.co.in

${ }^{2}$ Prof., Ph.D., Structural Engg., Faculty of Civil Engineering, Guru Nanak Dev Engineering College, , Ludhiana-141006, Punjab, India, e-mail:jsdhillon26@rediffmail.com 


\section{INTRODUCTION}

Over the years researchers have tried to take advantage of various optimization techniques to fulfill the requirements of safe and low-cost structural design. The structural design codes do not primarily dwell on the optimization front, and this factor is mostly based on the experience of a particular designer which, in any case, cannot be considered a substitute for the tested and validated principles of optimization techniques. However, for the vast varieties of structural options for a given requirement involving a large number of variables, any particular technique cannot cater to all structural optimization problems. A given optimization technique that gives good results in a particular situation may not be applicable for other situations, or, for that matter, on other fronts in the same situation. This leads to a point where it is important to be able to identify the usefulness of a particular technique in a given situation, and also to explore the factors that could increase the efficiency of the technique. Many evolutionary optimization methods have been developed during the last few decades for solving linear and nonlinear optimization problems such as genetic algorithms, harmony search, simulated annealing, particle swarm optimization, ant colonies, and hybrids obtained from combining of two or more algorithms, helping to explore solutions for constrained problems. Among all, a genetic algorithm (GA) - an artificial intelligence method inspired by biological phenomena has been widely used for structural design problems. Many researchers have used the approach of GA in their work to carry out optimization processes of RC frames (Camp \& Pezeshk 2003; Kwak \& Kim 2008; Kwak \& Kim 2009; Lee et al. 2003) [1-4]. Some of the previous studies focusing on obtaining optimum design parameters of RC frames based on Indian specifications have also implemented the capability of GA (Govindaraj \& Ramasamy 2007; Rajeev \& Krishnamoorthy 1998) [5-6], but hybrid algorithms have mostly been studied for truss structures (Gholizadeh 2013; Kaveh \& Talatahari 2008) [7-8] and have had limited application for reinforced concrete structures. The hybridization of algorithms has been performed to integrate the strengths of different algorithms and to overcome their weaknesses (Talbi 2002) [9]. Particle swarm optimization (PSO) is a preferred evolutionary technique in hybrid methods because of its simplicity and fast convergence, but standard PSO has certain inherent difficulties in making the right balance between global investigation of the search space (exploration) and a refined search around local optima (exploitation) (Kennedy and Eberhart 1995; Trelea 2003) [10-11]. To improve upon this specific problem of PSO, it was hybridized with other approaches such as Ant Colony Optimization (ACO) and Harmony Search (HS). Kaveh and Sabzi (2011)[12-14] compared HBB-BC and heuristic particle swarm ant colony 
(HPSACO) algorithms by considering optimization problems related to reinforced cement concrete (RCC) frames. Esfandiary et al. (2016) [15] used the basic concept of multi-criterion decision-making and combined it with particle swarm optimization to develop another algorithm (DMPSO) which accelerated convergence towards the optimum solution of a multi-objective structural optimization problem. Another researcher Rashedi et al. (2009) [16] introduced GSA, an algorithm based on the law of gravity and mass interactions. The algorithm is laden with many features like memory-less adaption, a self-learning profile, and fast convergence. Mirjalili \& Hashim (2010) [17] combined distinct capacities of PSO (social thinking capacity) and GSA (local search capacity) to propose PSOGSA. Meanwhile, the advantages of PSO (easy adaptability, smaller number of parameters to be adjusted, ability to go for global optima) were put to good use by the authors.

The present paper applies a hybrid of democratic particle swarm optimization (DPSO) and self-adaptive gravitational search (SA-GSA) algorithms- hereby called modified hybrid PSOGSA- for optimum design of RC frames. The objective of this study is to explore combined advantages of different algorithms that have not been earlier considered for hybridization, especially for the design of RC frames. The methodology consists of formulating the optimization problem on the basis of design variables, choosing a modified hybrid PSOGSA algorithm and comparing the results using the example considered in an earlier study.

\section{FORMULATION OF THE PROBLEM}

\subsection{OBJECTIVE FUNCTION}

The cost of reinforced concrete structural elements primarily includes the costs of concrete, steel, and formwork. Therefore, the objective function took the following form of Eq. (2.1):

$C=C_{C}+C_{s}+C_{f}$

$C$ - Total cost of structural element; $C_{S}$ - cost per unit volume of steel; $C_{C}$ - cost per unit volume of concrete; $C_{f}$ - cost of formwork per unit area.

$Z=\Sigma C_{\text {Beam }}+\Sigma C_{\text {Column }}$

$Z$ - Objective function for RC frames structure which includes the cost of all beams and columns of the frame.

$C_{\text {Beam }}=\left\{C_{c} b h L+C_{s} A L \gamma_{S}+C_{f} L(b+2 h)\right\} ; C_{\text {Column }}=\left\{C_{c} b h L+C_{s} A L \gamma_{S}+C_{f} L 2(b+h)\right\}$ 
$b, h$, and $L$ are the width, depth, and length of structural members respectively in meters; $A$ is the area of the reinforcing bars for each section in $\mathrm{m}^{2}$ and $\gamma_{S}$ is the density of reinforcing bar in $\mathrm{kg} / \mathrm{m}^{3}$.

\subsection{DESIGN VARIABLES AND CONSTRAINTS FOR BEAM OPTIMIZATION}

In the present study, all input design parameters have been considered fixed. These included span of beam, grade of reinforcement and concrete, intensity of dead and live loads, effective cover of concrete, and cost ratio. The independent design variables of the beam considered in this model are its width $\left(b_{B}\right)$ and effective depth $\left(d_{B}\right)$. The areas of longitudinal reinforcement and shear reinforcement were calculated as dependent design parameters. Designs constraints were considered in accordance with Indian codal provisions for RC beam design (IS 456: 2000) and other publications (Vergese 2013; SP: 16-1980) [18-20].

- Moment capacity consideration

- Deflection consideration

- Minimum width of beam

- Slenderness limit of beam from lateral stability consideration

- Depth of neutral axis

- Minimum and maximum reinforcement steel

\subsection{DESIGN VARIABLES AND CONSTRAINTS FOR COLUMN OPTIMIZATION}

Column optimization involves the determination of depth and width of the columns, with 'percentage area of longitudinal reinforcement' and 'ratio of depth of neutral axis to depth of column' as design variables. The following constraints have been considered:

- Axial load capacity of column

- Moment capacity of column

- Longitudinal reinforcement in column

- Minimum number of longitudinal rebars

- Maximum peripheral distance between longitudinal rebars 
- Cross-section of the column

\section{MODIFIED HYBRID MPSOGSA}

Determination of an optimal global solution among all possible inputs is the aim of implementing any optimization algorithm, and, to improve the performance, hybridization of two or more algorithms is performed. Several heuristic algorithms have been combined to form hybrid methods for optimization problems. The basic idea of combining Standard PSO with GSA was suggested by Mirjalili and Hashim (2010). They combined the social thinking ability of PSO and the search capability of GSA.

The 'interaction between particles' to determine the best position is the crux of the democratic particle swarm optimization technique (DPSO). The gravitational search algorithm (GSA) uses the "law of gravitation' for its notion of mass interactions in the search space. Since democratic PSO (DPSO) and self-adaptive GSA (SA-GSA) are improved versions of standard PSO and standard GSA, respectively, this paper has integrated the two enhanced versions to evaluate their combined performance through a new modified hybrid, i.e. MPSOGSA. There are two tuning parameters in GSA, namely $G(t)$ and $K b e s t$, which greatly affect its performance. Researchers have mostly used two ways of defining these parameters. Either their values have been kept constant throughout the process, or varied linearly using certain concepts, as mentioned by Rashedi and Nezamabadi-pour (2012) [21]. For example, $G(t)$ initialized at the start is made to vary linearly with time as follows:

$$
G(t)=G_{O}(t)+\left(\frac{t}{t_{\max }}\right)^{\beta}
$$

$t$ represents current iterations and $t_{\max }$ is maximum number of iterations.

Similarly, Kbest is reduced linearly starting from the total number of agents at the start to one at the end. There is no clarity on which rule for linear variation of these parameters to follow so as to get better results. The self-adaptive approach tries to overcome this problem by defining a range of these parameters and updating them stochastically within the range at each iteration, thereby bringing in selfadaptive concept to the GSA (Niknam et al.2013) [22]. 
The hybrid is a stochastic algorithm with a feature to randomly select the important parameters that have an influence on the search procedure. The advantage of implementing MPSOGSA is that it avoids getting trapped in local optima, and also improves upon premature convergence probability. It thereby reaches a better optimal solution in reasonable time. The functionality of both algorithms is combined and run parallel to each other. The modified velocity equation becomes as stated in Eq. (3.2).

$v_{i}^{d}(t+1)=w v_{i}^{d}(t)+c_{1}^{\prime} \cdot r \cdot a_{i}^{d}(t)+c_{2}^{\prime} \cdot r \cdot\left(p_{g}^{d}(t)-x_{i}^{d}(t)\right)+c_{3}^{\prime} \cdot r \cdot{d^{\prime}}_{i}^{d}(t)$

$v_{i}^{d}(t)$ represents the velocity of agent $i$ at iteration $t, c_{1}^{\prime}$ and $c_{2}^{\prime}$ are the positive numbers illustrating the weights of the acceleration terms guiding each particle towards the individual best and swarm best positions respectively. $c_{3}^{\prime}$ helps to control the weight of the democratic vector. $w$ is the weighing function, $r$ is a random number between 0 and $1, a_{i}^{d}(t)$ is the acceleration of agent $i$ at iteration $t$, and $p_{g}$ is the best solution so far. $d_{i}^{\prime}(t)$ - includes democratic influence of other particles on $i^{\text {th }}$ particle in $d^{\text {th }}$ dimension.

Each iteration updates the position of particles as (3.3):

$x_{i}^{d}(t+1)=x_{i}^{d}(t)+v_{i}^{d}(t+1)$

in which the time interval is equal to 1.0 , and thus the velocity vector can be added to the position vector. It is clear that the information produced by all members of the swarm moving with an acceleration guided by GSA, is utilized by the PSO with the purpose of determining new positions of each particle, and thus the phrase "modified PSOGSA".

\section{OPTIMAL DESIGN SOLUTION}

For the application of the current optimization technique, the constrained optimization problem has first been converted to an unconstrained one. The defined constraints are normalized and exterior penalty function is incorporated for any constraint violation, thereby constituting the unconstrained objective function (penalized objective function) as follows:

$Z^{\prime}=Z(1+C)^{\delta}$ 
Where $Z^{\prime}$ is the penalized objective function, $Z$ is the cost function, $\delta$ is a dimensionless parameter whose value has been taken as two [14], and $C$ is the sum of all constraint violations.

The values of other constants are:

$c_{1}^{\prime}=0.5, c_{2}^{\prime}=1.5, c_{3}^{\prime}=4, \in=10$

(MPSOGSA`s constants)

$G(t)_{\operatorname{Min}}=1, G(t)_{\text {Max }}=100$, Kbest $_{\text {Max }}=$ Max number of agents, Kbest $_{\text {Min }}=1$

The population size ' $\mathrm{N}$ ' and maximum number of iterations 'itr max ' have been fixed at 20 and 1000 respectively, and upper and lower bounds for the design variables have been defined for a random selection of the population. Stopping criteria has been defined as the 'maximum number of iterations'. The values of $G$ and Kbest have been updated stochastically within the pre-defined range. All optimization runs have been carried out on a standard PC with an Intel ${ }^{\circledR}$ Core $^{\mathrm{TM}}$ i3 CPU M350@2.27 $\mathrm{GHz}$ frequency and $3 \mathrm{~GB}$ of RAM. The algorithm has been coded in Turbo $\mathrm{C}++$ installed in Windows 7 on a 32-bit operating system.

The efficacy and efficiency of the present design algorithm (MPSOGSA) has been measured by considering design examples from reviewed literature. Necessary changes (in objective function, constraints, cost ratios etc.) required to bring in the sense of compatibility for comparing design have been done accordingly.

\section{Example 1 Three bay-four storey RC frame}

The optimum results from the present algorithm were obtained for a general example of a three-bayfourstorey frame (Kaveh and Sabji 2011) subjected to certain lateral and gravity loads as shown in Fig.1, with the following structural characteristics: service dead load $(D)=22.3 \mathrm{kN} / \mathrm{m}$, uniform service live load $(L)=10.7 \mathrm{kN} / \mathrm{m}, C_{C}=105 \$ / \mathrm{m}^{3}, C_{S}=0.9 \$ / \mathrm{kg}, C_{f}=92 \$ / \mathrm{m}^{2}$, and $\gamma_{s}=7850 \mathrm{~kg} / \mathrm{m}^{3}$, compressive strength of concrete $\left(f^{\prime} c\right)=25 \mathrm{MPa}$, and yield strength of steel reinforcement $\left(f_{y}\right)=415 \mathrm{MPa}$.

The columns (from ground level to roof level) on the outer sides (exterior columns) are considered to be in one group, whereas interior columns constitute the second group. The grouping of beams is also shown in Fig.1. The optimum process has been carried out with a swarm size of 20 and a maximum run number 
of 1000, which generates 20,000 evaluations. Furthermore, six different factored load combinations are considered, as suggested in ACI 318-11 design code (Eq. (4.2) - Eq. (4.4)):

$U 1=1.2 D+1.6 L$

$U 2=1.2 D+1.0 L \pm 1.4 E$

$U 3=0.9 D \pm 1.4 E$

The optimized results obtained are compared with results obtained from other hybrid methods, as shown in Table 1.



Fig.1 Geometry and loading of a three-bay four-storey RC frame 


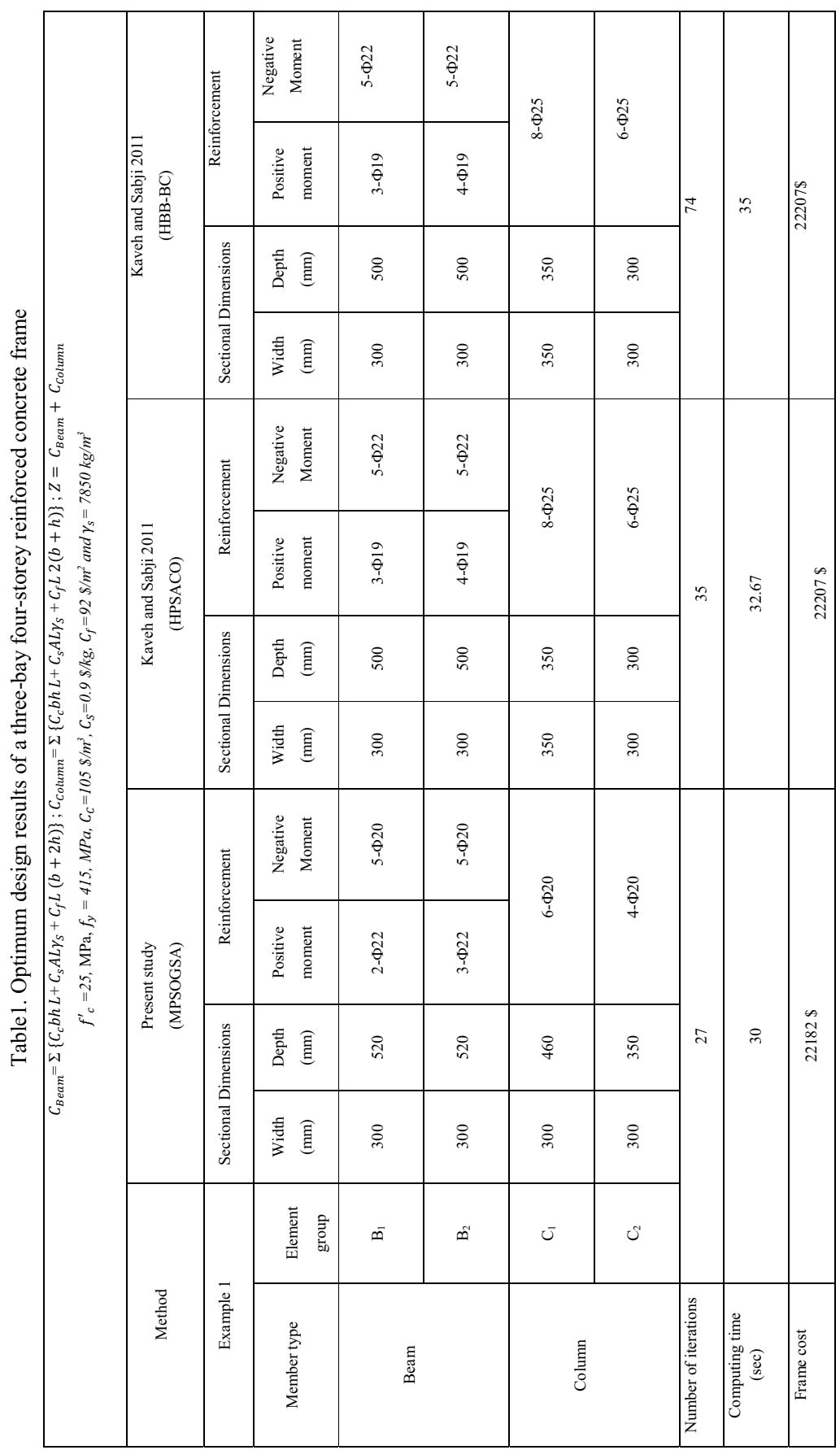




\section{CONCLUSIONS}

Analysis of RC frame structures has been performed using a direct stiffness approach with the design procedure following Indian standard IS 456-2000 regulations. Optimum design results are obtained via the use of a new modified hybrid technique (MPSOGSA). The proposed algorithm overcomes the limitations of two existing individual algorithms (modified PSO \& modified GSA) by considering their hybrid, thereby improving overall performance. Necessary changes have been incorporated to make the study compatible with an earlier study, and to help compare the results.

A comparison with other hybrid techniques used earlier reveals that the time taken to carry out the optimization process in the present study - by the use of MPSOGSA technique - has been reduced significantly. Also, reductions in total cost in the design of RC frames have been achieved using the MPSOGSA technique. Reductions of cost in the steel area play a greater role in optimization as compared to reductions in the cross-sectional area of frame elements, as is particularly verified in the example.

\section{ACKNOWLEDGEMENT}

This study is a part of Ph.D. research work carried out at IKG Punjab Technical University, Kapurthala (Punjab). The authors wish to express their gratitude to IKG Punjab Technical University for providing an opportunity to carry out this study.

\section{REFERENCES}

[1] C.V. Camp, S. Pezeshk and H. Hansson,"Flexural Design of Reinforced Concrete Frames Using a Genetic Algorithm." Journal of Structural Engineering ASCE, vol. 129, No.1, pp.105-115, 2003.

[2] H.Kwak and J. Kim, "Optimum design of reinforced concrete plane frames based on predetermined section database." Computer-Aided Design, vol.40, pp.396-408, 2008.

[3] H.Kwak and J. Kim, "Design An integrated genetic algorithm complemented with direct search for optimum design of RC frames." Computer-Aided Design, vol.41, No.7, pp.490-500, 2009. Available at: http://dx.doi.org/10.1016/j.cad.2009.03.005.

[4] C.Lee and J.Ahn,"Flexural Design of Reinforced Concrete Frames by Genetic Algorithm.” Journal of Structural Engineering ASCE, pp.762-774, 2003.

[5] V. Govindaraj andJ. V. Ramasamy, "Optimum detailed design of reinforced concrete frames using genetic algorithms.” Engineering Optimization, vol.39, No.4, pp.471-494, 2007. DOI:10:1080/03052150601180767.

[6] S. Rajeev and C.S. Krishnamoorthy, "Genetic Algorithm - Based Methodology for Design Optimization of Reinforced Concrete Frames." Computer Aided Civil and Infrastructure Engineering, vol.13, pp.63-74, 1998.

[7] S.Gholizadeh, "Layout optimization of truss structures by hybridizing cellular automata and particle swarm optimization."Computers and Structures, vol.125, pp.86-99, 2013. Available at: http://dx.doi.org/10.1016/j.compstruc.2013.04.024. 
[8] A. Kaveh, S. Talatahari, "A hybrid particle swarm and ant colony optimization for design of truss structures." Asian journal of Civil Engineering.vol.9, No.4, pp.329-348, 2008.

[9] E.G. Talbi, "A Taxonomy of Hybrid Metaheuristic." Journal of Heuristics, vol. 8, No. 5, pp. 541-546, 2002.

[10] J. Kennedy and R. C. Eberhart, "Particle swarm optimization" in Proceedings of IEEE international conference on neural networks, vol. 4, 1995, pp.1942-1948, 1995.

[11]I.C. Trelea, "The particle swarm optimization algorithm: Convergence analysis and parameter selection" Information Processing Letters. vol. 85, pp. 317-325, 2003.

[12]A. Kaveh and S. Talatahari,"Particle swarm optimizer, ant colony strategy and harmony search scheme hybridized for optimization of truss structures." Computer and Structures. vol. 87, No. 5-6, pp. 267-283, 2009.

[13] A. Kaveh and O. Sabji, "Optimum Design of Reinforced Frames using a Heuristic Particle Swarm -Ant Colony Optimization" Proceedings of second International Conference on Soft Computing Technology, Civil-comp Press. Stirbngshire, Scotland. 2011.

[14] A. Kaveh and O. Sabji, "A comparative study of two meta-heuristic algorithms for optimum design of reinforced concreteframes" International Journal of Optimization in Civil Engineering, vol. 9, No.3, pp.193-206, 2011

[15] M.J. Esfandiary, S. Sheikholarefin and H.A.R. Bondarabadi, “ A combination of particle swarm optimization and multi-criterion decision-making for optimum design of reinforced concrete frames." International Journal of Optimization in Civil Engineering, vol.6, No.2, pp. 245-268, 2016

[16]E. Rashedi, H. Nezamabadi-pour and S. Saryazdi, "GSA: A gravitational search algorithm.” Information Sciences, vol.179, pp. 2232-2248, 2009.

[17] S. Mirjalili, S.M. Hashim, “A new hybrid PSOGSA algorithm for function optimization.’'IEEE International conference on computer and information application (ICCIA'2010), pp.374-377, 2010.

[18] Code of Practice for Plain and Reinforced Concrete, IS: 456:2000 (fourth revision), (Bureau of Indian Standards: New Delhi, India) 2000.

[19]P.C. Vergese, "Limit state design of Reinforced Concrete." PHI Learning Private Limited, Delhi, 2013.

[20] SP: 16-1980, "Design Aids for Reinforced Concrete to IS: 456:1978”, Bureau of Indian Standards, Manak Bhavan, New Delhi.

[21]E. Rashedi, H. Nezamabadi-pour, "Improving the Precision of CBIR Systems by Feature Selection Using Binary Gravitational Search Algorithm." The $16^{\text {th }}$ CSI International Symposium on Artificial Intelligence and Signal Processing (AISP 2012) IEEE, pp.039-042, 2012.

[22] T. Niknam et al., “Multiobjective Optimal Reactive Power Dispatch and Voltage Control: A New OppositionBased Self-Adaptive Modified Gravitational Search Algorithm.’IEEE Systems journal.vol.7, No.4, pp.742:753, 2013.

\section{LIST OF FIGURES AND TABLES:}

Fig.1. Geometry and loading of a three-bay four-storey RC frame

Rys. 1. Geometria i ładowanie trójprzęsłowej czterokondygnacyjnej ramy RC

Tab.1. Optimum design results of a three-bay four-storey reinforced concrete frame

Tab. 1. Optymalne wyniki projektu trójprzęsłowej czterokondygnacyjnej żelbetowej ramy

Received 15.05.2017

Revised 01.02.2018 


\section{OPTYMALNY PROJEKT RAMY RC Z WYKORZYSTANIEM ZMODYFIKOWANEGO ALGORYTMU HYBRYDOWEGO PSOGSA}

Stowa kluczowe: optymalny projekt; konstrukcje żelbetowe; demokratyczna optymalizacja roju cząstek; samoadaptacyjny algorytm grawitacyjnego wyszukiwania; hinduskie standardy projektowania.

\section{STRESZCZENIE:}

W niniejszym artykule przedstawiono bardziej realistyczny i optymalny projekt żelbetowych ram konstrukcyjnych (RC) poprzez hybrydyzację ulepszonych wersji standardowej optymalizacji roju cząsteczek (PSO) oraz standardowy algorytm wyszukiwania grawitacyjnego (GSA). Podejście proponowane w niniejszej pracy koncentruje się na hybrydyzacji ulepszonych wersji standardowej optymalizacji roju cząsteczek (PSO) oraz standardowym algorytmie wyszukiwania grawitacyjnego (GSA). PSO została zdemokratyzowana poprzez uwzględnienie wszystkich dobrych i złych doświadczeń w zakresie cząsteczek, podczas gdy GSA został zmieniony na samodostosowujący, uwzględniając określony zakres dla niektórych parametrów, takich jak np. stała grawitacyjna i zestaw czynników o najlepszych wartościach sprawności. Optymalny rozmiar i wzmocnienie elementów zostały określone dzięki zastosowaniu techniki w środowisku komputerowym, w którym cały proces analizy, projektowania i optymalizacji został zakodowany w $\mathrm{C}++$. Procedura analizy i projektowania przebiega zgodnie ze specyfikacjami kodów indyjskich. Okazało się, że zastosowanie samodostosowującego algorytmu wyszukiwania grawitacyjnego wraz z demokratyczną techniką optymalizacji roju cząsteczek zapewnia dwie wyraźne przewagi nad standardową PSO i GSA, a mianowicie lepszą zdolność do ucieczki od lokalnej optymalności i szybszy współczynnik konwergencji. Całe sformułowanie dla optymalnego projektu kosztów ramy obejmuje zarówno koszt belek i słupów. W tym podejściu, zmienne każdego elementu ramy konstrukcyjnej zostały uznane za funkcje ciągłe i zaokrąglone odpowiednio do zastosowania praktycznego znaczenia niniejszego badania. Rozważono kilka przykładów, które podkreślają ważność optymalnej procedury projektowania, a wyniki porównano z wcześniejszymi badaniami, w celu sprawdzenia ich skuteczności i efektywności

Proponowany algorytm pokonuje ograniczenia dwóch indywidualnych algorytmów, biorąc pod uwagę ich hybrydę, a tym samym poprawia ogólną wydajność. Wprowadzono niezbędne zmiany, aby badanie było zgodne z wcześniejszymi badaniami. Porównanie z innymi wcześniej stosowanymi technikami hybrydowymi pokazuje, że czas potrzebny na przeprowadzenie procesu optymalizacji w niniejszym badaniu - z wykorzystaniem techniki MPSOGSA - został znacznie zmniejszony. Ponadto, podczas projektowania ram RC obniżono całkowity koszt za pomocą techniki MPSOGSA. Obniżenie kosztów w obszarze stali odgrywa większą rolę w optymalizacji, w porównaniu do redukcji kosztów w przekroju poprzecznym elementów ramy, co zostało szczegółowo przeanalizowane na przykładzie. 